\title{
Socio Technical Impact of Broadband Services in Baluchistan
}

\author{
Saira Ahthasham , Aftab Ahmed, Muhammad Javid Iqbal, \\ Ahthasham Sajid, Amir Shahzad \\ Department of Computer Science, BUITEMS, Quetta \\ sairaimtiaz@gmail.com \\ Department of Computer Science, BUITEMS, Quetta \\ aftab.ahmed@buitms.edu.pk \\ Department of Computer Science, SBKWU, Quetta \\ javaidkm@yahoo.com \\ Department of Computer Science, BUITEMS, Quetta \\ ahthasham.sajid@buitms.edu.pk \\ Department of Computer Science, BUITEMS, Quetta \\ Amir.Shahzad@buitms.edu.pk
}

\begin{abstract}
Broadband infrastructure is a key component of knowledge economy. Broadband service both on fixed and mobile networks are becoming an indicator of the knowledge economy. Globally it is viewed that countries with developed broadband infrastructures are working more efficiently and effectively towards social and economic growth. To achieve worldwide broadband connectivity level Government of Pakistan and industry must play a combine role for the betterment and improvement of the said industry. Government and market players must come up with innovative broadband packages that can capture the customer demand. This paper analysis market trends, customer expectation and socio-technical impact of broadband service in Baluchistan.
\end{abstract}

Keywords: DSL, Cable, Fiber, WiMAX, HSDPA, LTE, UMTS, CDMA, TDMA

\section{Introduction}

In last few decades Information and Communication Technology (ICT) has transformed the world. The potential of ICT helping in reducing poverty, healthcare delivery, trade facilitation, distance education, spreading knowledge and nurturing economic growth in 
developed and developing country has been widely recognized. Policy makers all over the world have accepted the fact that ICT can provide key inputs for economic development, improve public sector efficiency, effectiveness and transparency however, it is not a magic bullet but rather just one element of the development process. International experience has shown that benefits of ICT can only be seized only in favorable economic, regulatory and political environment.

The penetration rate of internet in world population is only $28.7 \%$. Pakistan is on $8^{\text {th }}$ number as per internet users survey 2009 with 18.5 million users which has increased up to $50 \%$ in $2010[1]$.

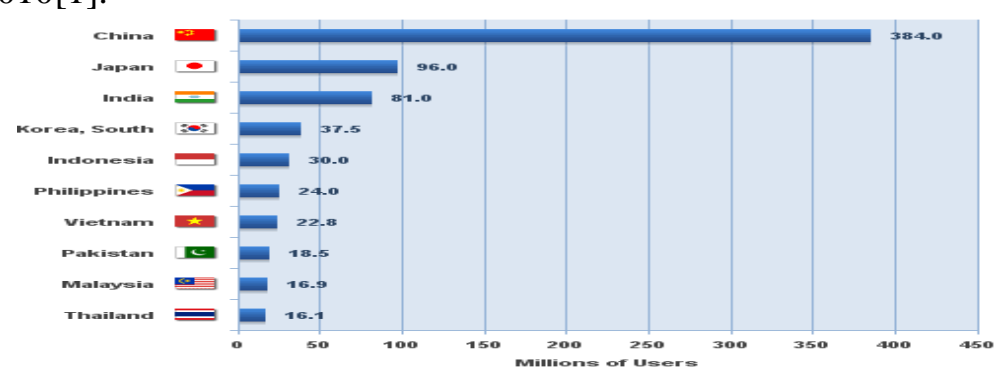

Figure 1: Internet in Asia -2009 Top 10 Countries [2]

Access to broadband internet is expected to increase GDP growth and facilitate the whole development value chain process due to the benefits that broadband internet will have on organizations efficiency.

Price plays a major part in broadband internet access. Due to the positive policies adopted by the government the cost has come down almost $90 \%$ since 2000 [2] but the reality remain that it's still a considerable cost for a household when compared to other narrowband connections. Households with meager budgets are simply unable to afford the luxury of having a broadband internet connection under current pricing policies and practices. The current growth of broadband access is exclusively taking place in high income Pakistani households while failing to grow for low income or middle income households.

\section{Broadband and Deployment Technologies}

Broadband is basically a connection of high data rate to the Internet as compare to dial up. Broadband services offer in four different forms i.e. Cable, Fiber optic, Satellite and DSL. Broadband could also be defined as a high speed always on Internet connection [3]. Broadband offers high speed internet access to enjoy the online contents and advance technologies available today. With this service one is able to transfer audio and video files much quicker than it was possible to do using narrow band dial up connections. In year 2007 the worldwide total of broadband subscribers stood at 313.6 million [4] depicted in figure2. 


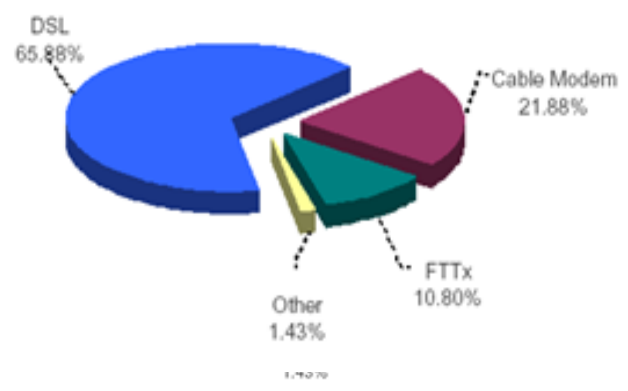

Figure 2: Total Broadband by Technology [4]

\subsection{Broadband Market of Pakistan}

Broadband services has globally identify as parameter for calculating the economic and social development of any country. In comparison with telephone, it is one of the widely used medium of exchange for information around the globe. Through the advent of broadband people has achieved easy and cheaper way of communication and particularly for field of business \& commerce. Presently it has become impossible for business to carry on without the use of broadband and it has become more important when a business has to work outside a country borders. In addition the broadband network has become a vital part of daily communication, education, hospital \& health facilities and even for the Government. Utilization of broadband has increase the performance and quality of the every sector and aspect of economy. Economists around the world are seriously suggesting broadband as basic necessity for GDP and economic uplift of a country. They are viewing it as platform with multiple economic \& social impacts. It is believe that with advent of broadband, in IT revolution can be brought through with moral of economy and people can be raise.

Globally attentions have been paid on highlighting the importance of IT and broadband. For the said purpose many meetings /conventions has been held around the world. Among such gatherings, two Summits are of very importance. First was detained in Geneva in year 2003 and second was held in Tunis in year 2005. In these Summits it concluded that Information access \& sharing must be given to everybody for knowledge creation that can significantly contribute to strengthening economic, social and cultural development. Information is a fundamental driver of increased efficiency and worldwide competitiveness in this age of IT revolution. It is shaping the future by providing opportunities to information, invention and wealth creation. Economic processes at global level are increasing influence on creation, distribution, gathering and execution of knowledge and information [5]

Researchers / studies have been carried out over the last few years, revealing the economic \& social benefits of broadband deployment around the globe. A study 
by Dataquest Inc. estimated that "the implementation of broadband could result in an incremental increase in the US gross domestic product of as much as $\$ 500$ billion annually for each of the next 10 years" [6].

Another study done by (Robert Crandall and Charles Jackson) estimated "that benefit of broadband to the United States to be upwards of $\$ 500$ billion per year within the next 15 to 25 years if broadband was to become nationally [7].

Soon afterwards policy makers had seen the potential $\&$ started to recognize the potential of broadband internet access for socio economic development. A Proposal was invited from various companies in order to make a public email service. As a result licenses were granted to sixteen companies for Internet and email services in Feb 1996. Digicom in 1995 for the first time launched Internet services in Karachi. Internet service was connected by a $64 \mathrm{Kbps}$ link to the global Internet. The Pak Net data network was operated by PTCL (Pakistan Telecommunication Limited) in 1996 to deliver improved Internet services as well. Pak Net was connected by $512 \mathrm{Kbps}$ link to the global Internet. The advent was initiated and by mid of 1997 Internet Service Providers were working in five different cities of the country. By mid of 1999 approximately 100 organizations licenses had been issued for Internet services providing, from which 50 were operating [8].In Pakistan the community of Internet user had been started growing steadily since 1995.

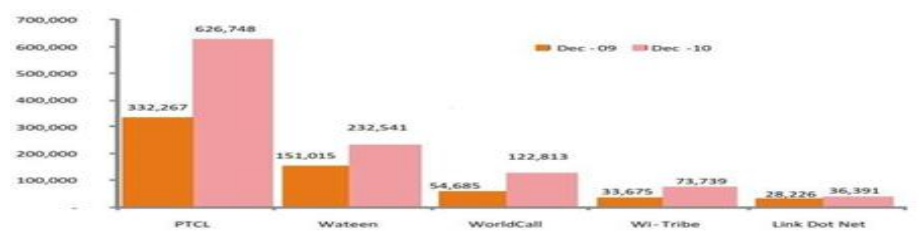

Figure 3: Broadband subscribers by operator [9]

The figure 3 shows number of ISP operating in various cities of Pakistan. Since most ISPs were based in major cities most of the population living in rural areas had to pay heavy charges due to distance. Pakistan lacked the basic infrastructure for broadband. The only way out for the ISPs is to lease the lines from PTCL to carry their own traffic. In case of connecting with the worldwide Internet, ISPs had to lease rather costly international circuits from PTCL. Such all issues have lead to an increase connectivity cost that ISPs had to impose on the subscribers/customer in the shape of subscription rates. In Pakistan the charges of Internet service subscription were mainly based on usage. Average ISPs charging rates were just about $\$ 1.80$ per hour during daytime hours while for off peak periods the rated declines to around $\$ 0.80$ per hour. Some progress has been made in this industry in 2000 when network access points were created in Karachi and Islamabad. The basic functions of these points were to control the internet traffic 
to local cities. In all these years, although the broadband industry has shown a tremendous development by providing internet in more than 2000 villages and towns and decline in international bandwidth rates by almost 90\% (from USD 30,000 to USD 3,950), still the internet usage in Pakistan is below international average showing a lot of room for improvement.

The Govt. of Pakistan has also realized the importance of broadband and they have started considering it very important. In this regards PTA took a major steps in 2004 and allowed all ISPs to provide broadband services with very less restriction. On the other hand a Broadband Policy was also announced by Government with aim to make the Pakistan Market more favorable for the ISPs. The policy mainly aims for high speed internet at reasonable price while simultaneously promoting private sector for investment in the said sector. The primary object of the policy was to increase number of broadband users to 500,000 within next five years [11].

According to the latest figures published in PTA (Pakistan Telecommunication Authority) annual report 2007 [12] the number of broadband subscribers is around 79,040 which provides the picture of how poor state is the broadband market of Pakistan is in when compared to other similar economies.

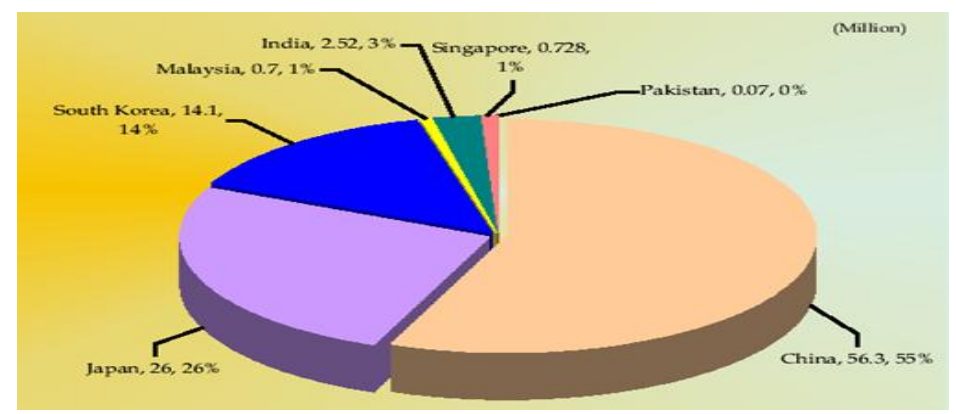

Figure 4: Broadband Subscriber is Asia IDC 2007 [12]

Table 2.1: Pakistan Internet Facts

\begin{tabular}{|l|l|}
\hline Estimated Internet clients: & $3-5$ millions \\
\hline Estimated Broadband Internet customers: & 79,040 \\
\hline O2 MB cost of IP connection: & USD 1,600 per month \\
\hline Internet bandwidth to Pakistan: & $\begin{array}{l}2,324 \mathrm{MB} \text { (PIE) } \\
620 \mathrm{MB} \text { (FLAG) }\end{array}$ \\
\hline Operational ISPs: & Approximately 60 \\
\hline ISPs providing DSL services: & 8 \\
\hline Broadband Internet via cable provided by HFC Operators: & 2 \\
\hline Undersea cables connecting Pakistan to rest of world: & $\begin{array}{l}2 \text { with PTCL (www.ptel.com.pk) } \\
1 \text { with TWA (www.twal.com) }\end{array}$ \\
\hline Registered Domains under -pk domain: & 13,500 \\
\hline
\end{tabular}




\section{Research Methodology}

The research is mainly based on qualitative research design. For the said purpose descriptive or survey research design is used to collect, interpret $\&$ analyze the data that is gathered through primary and secondary sources of information. Primary data will be collected using the pre described tools i.e. Questionnaire and Interview. Initially, the primary collected data will be arranged and organized into charts \& graphs. Secondly, on the basis of interview and secondary data, interpretation of the charts, graphs and table would be done in order to provide possible solutions for the problem statement of the research.

\section{1: Sampling Technique/ Size}

The sample size surveyed for the proposed research consists of the following:

- Pakistan Telecommunication Limited

- Broadband Service Providers

- Randomly chosen Household \& commercial users

\section{$4 \quad$ Survey Analysis \& Results}

This research work deals with the analysis of data collected from the respondents through the tools of questionnaire \& interview. For the said purpose a number of 150 respondents were inquired. Out of the total sampled data, 100 respondents were found accurate for analysis. The response obtained from the respondents in terms of questioned asked is analyzed as under:

\section{1: Gender and Age Trend}

As per result shown in figure 5, majority of the sample size is male in the business community. The ratio of female is comparatively very low in business community of the population. Fig 6 elaborates age group of sample size at household and commercial level. In household people of age group of 18-28 owns most of the connections i.e. $91.3 \%$ as compare to $62.0 \%$ of commercial users. While on the other hand the people of age groups $29-39 \&$ above 39 are found as $8.0 \% \& 0.7 \%$ for the household as compare to $23.0 \%$ \& $15.0 \%$ for commercial users respectively.

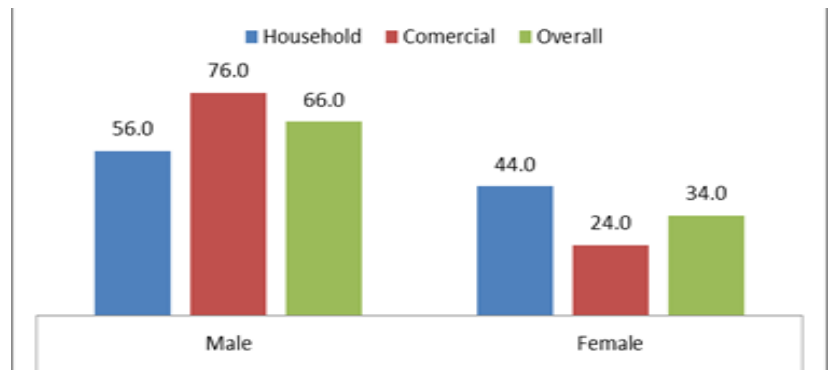


Fig: 5

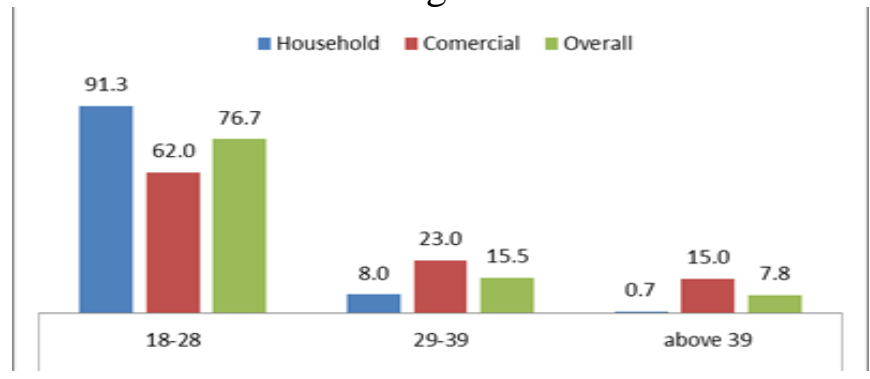

Figure 6: Age group

\section{2: Users Expertise In Information Technology?}

In figure 7 it is obvious that majority of the respondents are categorized in Average level i.e. $52.3 \%$ followed by Learner $29.5 \%$ and finally $18.2 \%$ as skilled. Comparing the two groups, it is evident that commercial users got more expertise as compare to household customers.

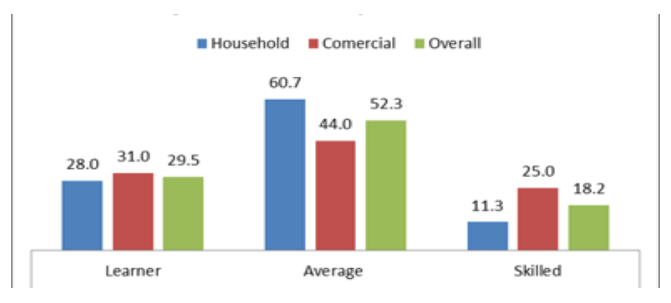

Figure 7: IT expertise level

\section{5: Internet Usage Purpose (Commercial or Household)}

As depicted in figure 8,60\% users belong to house hold group while $40 \%$ were using it for commercial activities.

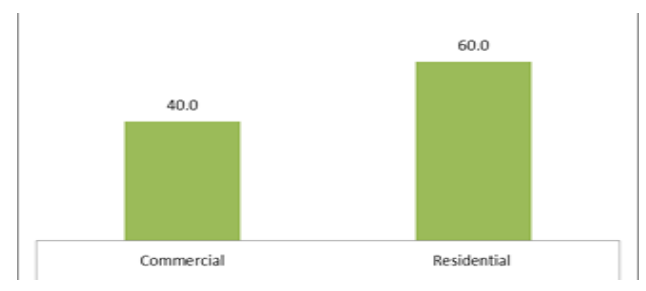

Figure 8: Connections type 


\section{6: Organization / Business Category?}

This question only deals with the occupation characteristics of both commercial \& household users of the sampled respondents. Following figure 9 depicts that government /semi- government group constitute majority of the respondents followed by educational institutes.

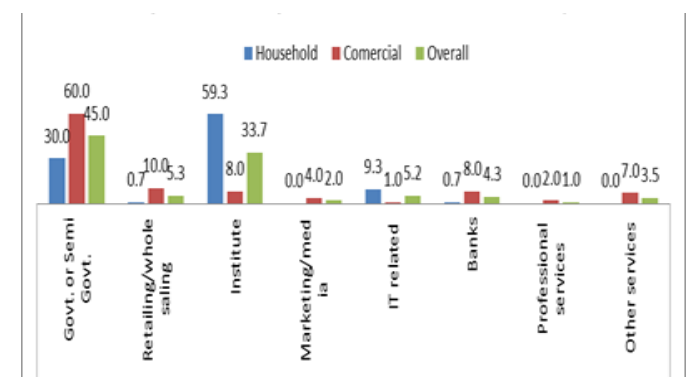

Figure 9: Organization/Business Activity

\section{7: Internet Connection Penetration}

Figure 10 shows that $82.7 \%$ have subscribed for an internet connection from household group against a percentage of $61.0 \%$ from the commercial group. Summing up to average of $71.8 \%$ of sampled data, who have subscribed for internet connection?

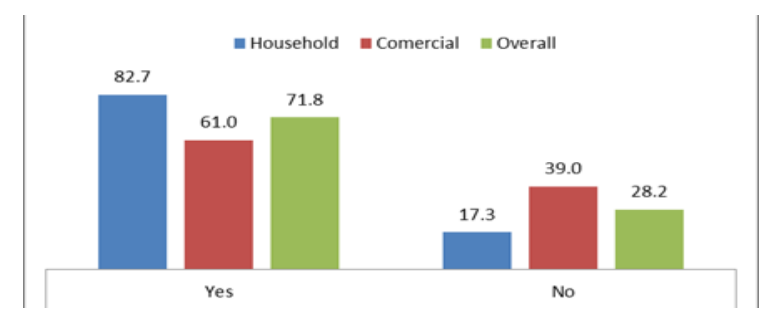

Figure 10: Internet subscription

\section{8: ISP Providers}

Figure 11 illustrates the results/opinions of the respondents. It is obvious that DSL is most widely used technology. In household customers $99.2 \%$ people used DSL (PTCL) followed by Link.net. 


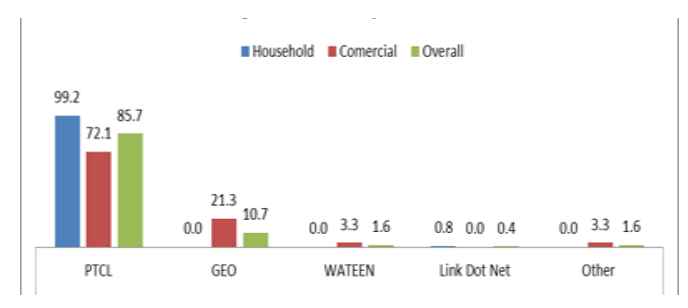

Figure 11: Preferred ISP

\section{9: Usage Hours?}

Figure 12 illustrates that majority of the users use broadband connection for less than 3 hours i.e. $52.3 \%$.

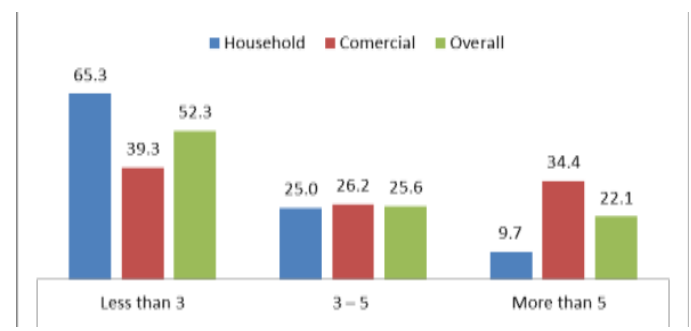

Figure 12: Broadband hourly usage

\subsection{0: Number Of Person Uses The Broadband Bonnection?}

Figure 13 portrays the data collected regarding the usage of broadband in term of number of person. According to statistics reveled from the survey a broadband connection is used by less than 5 people by around $59.6 \%$ respondents. In household group, the person usage of broadband are $84.7 \%, 13.7 \%$ and $1.6 \%$ for Less than 5 person, 5-10 person and more respectively against the person usage of $34.4 \%, 34.4 \%$ and $31.1 \%$ for the commercial group.

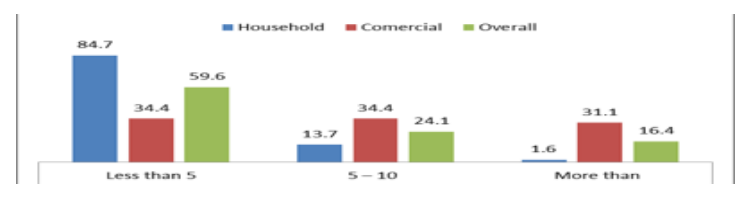

Figure 13: Broadband person usage

\subsection{Customer Satisfaction Trends}

Figure 14 summarizes the findings, according to which majority of respondents are declared as average i.e. $68.3 \%$. The other results include $14.2 \%, 13.5 \%$ \& $4.1 \%$ for satisfaction level of high, below average \& dissatisfied respectively. 


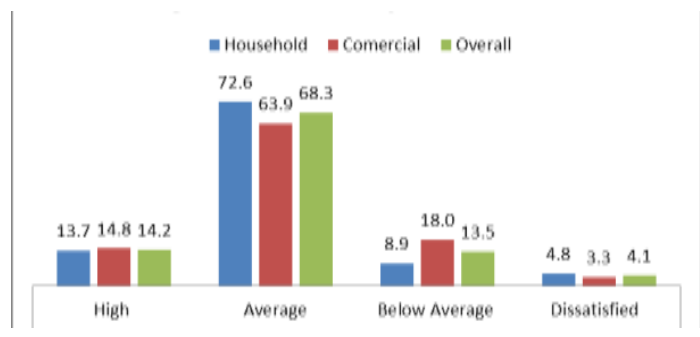

Figure 14: Satisfaction level

\subsection{2: Desire To Change Your Connection?}

Figure 15 illustrates the data concerning the viewpoint of respondents regarding changing their service. The question was inquired in light of the previous question. Comparing the results with the previous question it is clearly indicated that the major percentage of the respondents are in favor of changing the connection for a better service. As per results, $61.8 \%$ of the respondents favor the change against $38.2 \%$ respondents. At group level, $65.6 \%$ of commercial users favor the change against the $58.1 \%$ of household customers.

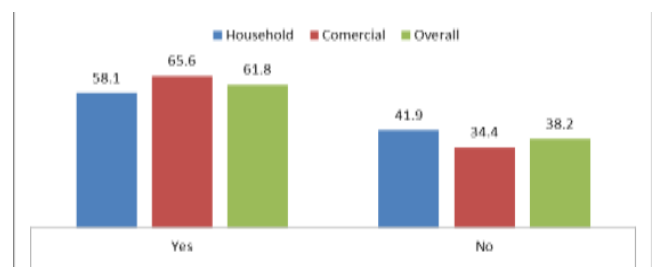

Figure 15: Connection change preference

\subsection{3: Users Perspective On Cost To Value Trends}

Figure 16 shows the perspectives of respondents regarding willingness for a better service even on a high cost. The results clearly indicate that customers do inquire for a better service but high majority of them aren't willing to pay high cost for the said reason. As per results on average basis a percentage of $63.0 \%$ don't favors a better service with high cost against $37.0 \%$ of customers, who are willingly to pay high cost for better service. 


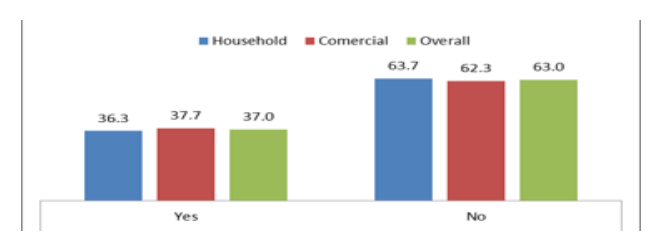

Figure 16: High cost service

\subsection{4: Technology Advancement in Broadband}

Figure 17 depicts that around $87.8 \%$ of the respondents welcome new technologies \& consider it as development. At group level, $91.9 \%$ household and $83.6 \%$ commercial users favor the advent of new technology. However some portion of percentage around $12.2 \%$ is against the phenomenon. There is strong need for brining improvement in the national broadband industry to coup up with global broadband revolution.

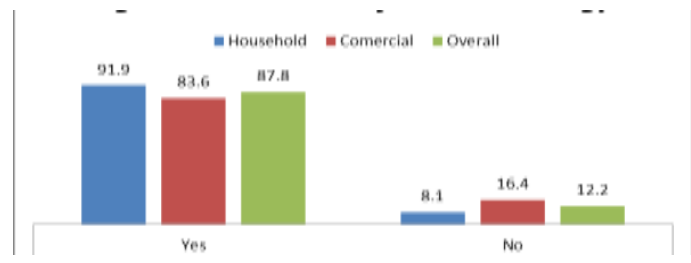

Figure 17: Advent of new technology

\subsection{5: Adoption of New Technology}

The above cited question relates to the previous question. This question deals with perception of respondents that if a new technology is introduced in Pakistan will it be accepted in every related field. Figure 4.15 shows the perspective that around $74.8 \%$ respondents believes that the new technology will easily be accepted in every aspect of social \& professional life against $25.2 \%$ respondents who believes that the new technology can never be easily accepted in every aspect of life. 


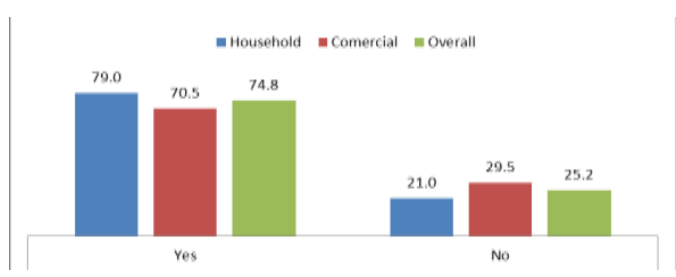

Figure 18: Acceptance of new technology

\subsection{6: Broadband Connection for Business/Profession?}

The described question deals with perception of respondents regrinding the importance of broadband service for their business or respective professions. Figure 19 illustrates the result that an average of $47.9 \%$ respondents strongly agree with the statement followed by Agree, Don't know, Disagree and Strongly disagree in percentages of $41.9 \%, 6.9 \%, 1.6 \%$ and $1.6 \%$ respectively.

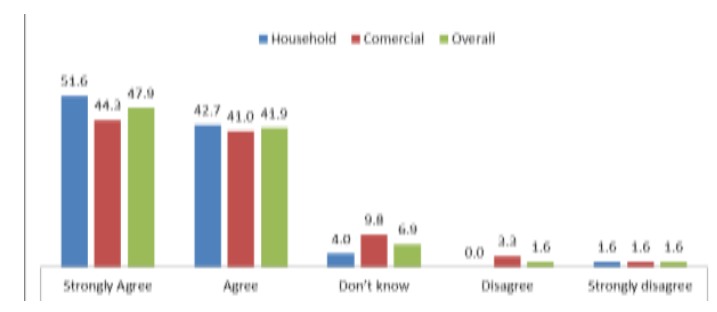

Figure 19: Importance of broadband

\subsection{7: User's Basic Criteria for Choosing a Broadband Service}

The question deals with the perception of broadband users concerning with four primary criteria for choosing a broadband connection. Figure 20 shows the response received as $41.9 \%$ respondents believe that speed is the major criteria for choosing a broadband connection. The other mainly influence by quality as $34.1 \%$ respondents believe quality as basic standard for choosing a connection. In addition to above two, some perceive availability \& cost as basic standard in percentage of $15.4 \%$ and $8.6 \%$ respectively. At group level, the percentages of household respondents are $41.1 \%, 33.9 \%, 19.4 \% \& 5.6 \%$ for favoring speed, quality, availability \& cost respectively against an almost similar response by the commercial customers. 


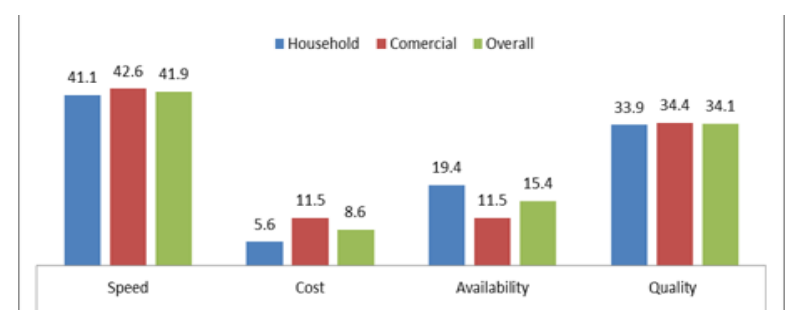

Figure 20: Basic criteria

\subsection{8: Major Barriers Faced By Broadband Market}

Figure 21 expresses the views of sample group regarding the major barriers faced by broadband industry. Majority of the person believes that unavailability of infrastructure is the biggest hurdle faced by broadband industry. As $39.5 \%$ respondent favoring this argument. Other views regularity, social \& low demand as major barrier in $23.1 \%, 22.7 \%$ and $14.6 \%$ of the total respondent's percentage.

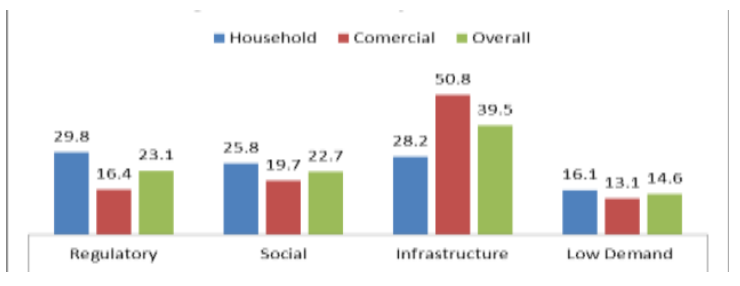

Figure 21: Major barriers

\subsection{9: If You Don't Have a Broadband Connection, Why?}

Figure 22 illustrate the question deals with the opinions of some percentage of respondents who are not subscribed to any broadband service as asked in question 3. This question was asked to observe the reasons behind this. In relevance with the statistics, it reveals that $56.4 \%$ percentages of the respondents are not using any particular service due to the unavailability. In addition some of the respondent's percentage is not using any service because they found it unrelated i.e. $24.4 \%$. While some of them consider the prevailing ISPs very poor i.e. $12.2 \%$ followed by $7.1 \%$ percentage who believes it expensive.

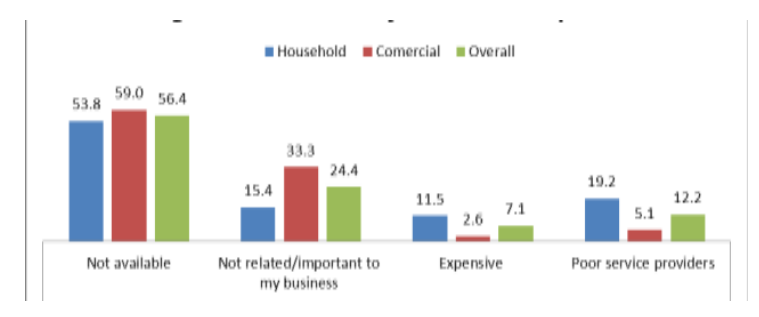

Figure 22: Reason for not subscription 


\subsection{0: In Case Of Subscription, Which Service Would You Prefer?}

The above cited question was asked in light of the previous question. If any respondent is asks to subscribe for any broadband service, which service he/she will prefer. Figure 23 describes the $72.4 \%$ of respondents were in favor of DSL (PTCL) as the most suited service. While on the other hand, services like Fiber, Cable, WiMax, Mobile broadband \& Wireless are preferred as 7.1\%, 1.9\%, 1.3\%, $3.8 \%$ and $13.5 \%$ respectively.

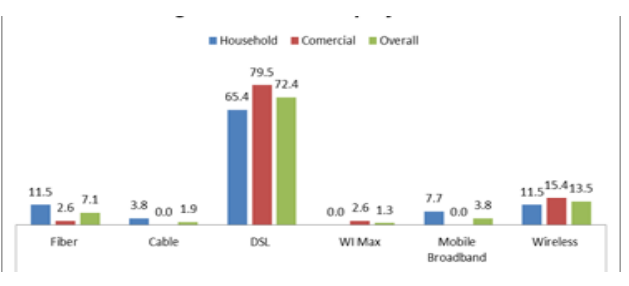

Figure 23: Service preference

\section{Conclusion}

The broadband industry has a potential demand with in the country for both household and business customers. Broadband has becoming a vital aspect of life such as way of communication \& entertainment etc. Majority of the customers aren't satisfied from their respective ISPs due to the poor quality and after sale service. Broadband industry has not reached to its maturity even after so many years. A competitive \& mature market must be established through proper support of Government. People, professional and institutes demand better ISPs who are providing customized service according to customer's needs and wants. Customers especially from the household sector, demand better service on cheaper rates. Among the broadband packages DSL is widely used within household and business community. The others such as Fiber, Wi Max, Cable, Mobile broadband and Wireless used according to customers will. Speed \& quality are primary requirement of Business customers while Speed \& Cost are major concern of household customers. The broadband industry has not reached to its maturity and still in many areas the broadband industry not reached. Broadband industry suffers through lack and poor quality of infrastructure. To develop the broadband industry in Pakistan it is important to open up the fixed line sector and invite more competition. Furthermore, I conclude my thesis by suggesting some recommendation through which the broadband industry in Pakistan can be made more efficient and effective for users and as well as for country economy. 


\section{$6 \quad$ Recommendations}

On the basis of the research analysis and conclusion it is recommended that for Pakistan to achieve worldwide broadband connectivity, the Government of Pakistan \& industry core actors must play a combine role for the betterment and improvement of the industry. On the primarily basis, focus must be given by the Government on account of policies favoring \& sustaining the growth of broadband industry in accordance with internationally followed principals and procedures. Government \& market players must come up with innovative broadband packages that can capture the customer demand. Moreover these packages must be provided in customized shape as per expectations of the customers. Although some packages has been provided fulfilling the described criteria but their scope is limited to some major cities. Efforts should be done to spread such services around the country. Following heading contains some major recommendations for betterment of broadband industry.

\section{1: Attracting The Low Earnings Communities:}

The Broadband services are commonly perceived as luxury in low income community of Pakistan. Internet Service Providers are working hard to reach \& provide the broadband services to this group but the adaptation rate of this community is very slow as compare to the lead class of Pakistan. Pakistan is country with majority of the middle class, so it has become very important for the ISPs to capture this huge market by removing the perception of broadband as luxury. The middle class of Pakistan has limited resources and the cost associated with installation and maintenance of broadband service is appearing to be high and out of reach for this class. On the other side, it is becoming very difficult for the ISPs to capture this huge market by providing the service at relatively low price. Government must take step and provide subsidy to ISPs in doing so. However the concept of economies of scale and highly competitive environment can be deploy in such circumstance for the betterment of country and industry in particular.

\section{2: Innovative Pricing:}

The concept of innovative pricing can be suggested for the broadband industry. The said concept is not seen in practiced by ISPs as compare to phone industry which is successfully using this concept in both wire line and wireless. ISPs can facilitate their customers with low price package having limited usage time. Otherwise the same package can be proposed on bit basis. Here comes the responsibility of government institutes as PTA. If such plans are backed by Government subsidy in any shape, the ISPs will be more motivated in capitalizing this potential. 


\section{3: Financial Digital Literacy Program:}

The majority of Pakistan's Population is characterized by lack of computer knowledge and illiteracy. Such factors are another big hurdle in the promotion of broadband services within the country. As compare to industry like telephone which is relatively easy to use, usage of broadband services do requires a sound background of the same filed. Government must subsidize this sector by providing incentives like USF. Moreover Government and organization must start campaigns for increasing awareness in the people in order to create a educated society and strong market for broadband services. For the said purpose facilities of computers and internet requires courses and diplomas for understanding and usage can be given free of cost to individuals.

\section{4: Provision Of Incentives On Usage Of Government Services:}

If incentives have given to low earning individuals for using broadband services, large number of customers can easily be attracted. For example instead of using mail, telephone or in personal channel in daily communication for government purpose, if email and broadband is used, a lot of money can save a lot for the government. On the contrary, Government can use this saving as provision of financial incentives to those people. To this way many persons can be motivated for using broadband services.

\section{References}

[1] http://www.internetworldstats.com/stats.htm

[2] http://www.internetworldstats.com/stats3.htm

[3] "Connecting Europe at High speed: National Broadband Strategies", http://ec.europa.eu/information_society/eeurope/2005/doc/all_about/broadband/co m_broadband_en.doc

[4] World Broadband Statistics Q2 2007”, http://www.iec.org/newsletter/dec07_2/analyst_corner.pdf

[5] Bruce Lai and Gale A. Brewer, "New York City's broadband problem and the role of municipal government in promoting a private-sector solution", (UNCTAD 2006) UNITED NATIONS PUBLICATION ISBN 92-1-112700-9.

[6] "Report on Broadband Access Technologies", http://www.itu.int/dms_pub/itud/opb/stg/D-STG-SG02.20.1-2006-PDF-E.pdf

[7] "Broadband Access", http://www.tiaonline.org/policy/initiatives/broadband/documents/broadbandpaper oct03.pdf,

[8] "Overview of Market Dynamics", http://www.thenews.com.pk/daily_detail.asp?id=37559

[9] http://southasiainvestor.blogspot.com/2011_05_01_archive.html 
[10] "PTA Quarterly Reports",

http://www.pta.gov.pk/index.php?option=com_content\&task=view\&id=1033\&Ite $\operatorname{mid}=225$

[11] www.pta.gov.pk

[12] http://www.pta.gov.pk/index.php?option=com_content\&task=view\&id=10

$33 \&$ Itemid $=225$ 